\title{
Turkey's Position in the Libyan Crisis
}

\author{
EMRAH KEKILLi* and BILGEHAN ÖZTÜRK ${ }^{* *}$ \\ * SETA, Turkey \\ ORCID No: 0000-0002-8430-1163 \\ ** SETA, Turkey \\ ORCID No: 0000-0003-1936-988X
}

ABSTRACT This paper discusses Turkey's relations with Libya, especially after the latest ground-breaking and rapid developments that took place in Libya such as Khalifa Haftar's attempt to invade Tripoli, the signing of two memoranda of understanding between Turkey and the Government of National Accord (GNA) and the dramatic change in the military situation of the country. It argues that Turkey's military support changed the positions of many domestic and external actors in Libya by tilting the balance of power in favor of the GNA.

Keywords: Turkey, Libya, Government of National Accord (GNA), Military Cooperation 


\section{Introduction}

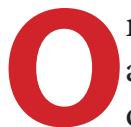

n November 27, 2019, Turkey and Libya signed memoranda of understanding (MoU) on the delimitation of maritime jurisdictions and security and defense cooperation. The Turkish Parliament's authorization to deploy Turkish troops to Libya on January 2, 2020 attracted public attention. These steps were taken in line with and against the backdrop of the deep historical background of Turkish-Libyan relations.

Turkish-Libyan relations have 500year historical background. Going back to the sixteenth century, the bilateral relations bring about a deep sense of responsibility in Turkey's Libya policy. Above all, Turkey has preferred becoming a constructive actor, taking a leading part in damping out conflicts and crises and prioritizing political negotiations over military approaches. While bringing the principle of the protection of civilians into the forefront during the revolution in 2011, Turkey made every endeavor to assist in the reconstruction of Libya until the eruption of conflict in May 2014. Then, Turkey supported the United Nations (UN) initiative for the resolution of the conflict through political means, as well as the Libyan Political Agreement (LPA) and the resultant institutions that were created in late 2015. Khalifa Haftar's insistence on a 'military solution', his rejection of all agreements and finally his attack on Tripoli on April 4, 2019, added a different dimension to the Libyan crisis. Having closely followed the course of the Libyan crisis since
2014, Turkey concluded that Libya would be dragged into a deeper crisis, as all efforts for a political solution were fizzling out due to the isolation of the Government of National Accord (GNA) vis-à-vis Haftar's incursions. Hence Turkey took the necessary steps to cooperate with the GNA to halt Haftar's march and render a realistic political negotiation possible in the Berlin Conference, which convened on January 19, 2020. This paper will discuss Turkey's relations with Libya since the 2011 revolution, with particular focus on Turkey's support to the GNA for a political solution of the Libyan crisis.

\section{The Libyan Revolution and Turkey's Attitude}

When the revolution erupted in Libya in 2011, taking into consideration the difficulty of Gaddafi's leaving the country and removing the traces of the regime altogether, Turkey concentrated on a plan that envisaged the introduction of reforms and Gaddafi's transfer of power. Since Gaddafi did not find the option of transfer of power favorable and later used force against civilians in Benghazi, Ajdabiya, and Ra's-Lanuf and killed many, Turkey endorsed UNSC Resolution 1970, even if partially. Although Turkey considered the resolution necessary, it did not prefer the inclusion of a clause that would make Gaddafi's trial at the International Criminal Court (ICC) possible. The inclusion of the clause meant that even if Gaddafi made reforms and transferred power, he still could face 
trial at the Court, which actually cornered him and made him to resort to harsher measures. In fact, after the UN resolution, Gaddafi forces started to attack rebels with much heavier and more lethal weaponry, increasing the intensity of clashes and the number of civilian deaths. This outcome proved that Turkey's initial concerns were not groundless.

Once military intervention started as per UNSC Resolution 1970 and Gaddafi's counter-attack, events in Libya took yet another twist. After that, Turkey built its policy on the premises of preventing the transformation of the military intervention into an invasion, protecting civilians, and adhering to UNSC Resolution 1973. As a passive member of the military intervention, Turkey concentrated its main efforts on the cessation of hostilities while supporting the protection of civilians, the imposition of the arms embargo on Libya, and the delivery of humanitarian aid. From the onset of the revolution, Turkey had prioritized the humanitarian crisis and expressed concerns over the possibility that the post-conflict 'order' would bring the country to the verge of a new conflict by creating entrenched animosities. When it became clear by June 2011 that a solution with Gaddafi was not likely, Turkey ruled out all options involving Gaddafi and recognized the National Transitional Council (NTC) as the legitimate authority in Libya. ${ }^{1}$ Turkey recognized that a political change in line with the legitimate demands of the people was inevitable, and an emphasis on a 'unitary and indivisi-

\section{Turkey recognized that a} political change in line with the legitimate demands of the people was inevitable, and an emphasis on a 'unitary and indivisible Libya' constituted the essentials of Turkish policy

ble Libya' constituted the essentials of Turkish policy. Turkey's support to the new administration was not limited to recognition; Ankara also pledged to give $\$ 300$ million to Libya for overcoming the crisis in Libya and contributing to the solution of the problems of the people.

\section{Turkey's Libya Policy after the Revolution}

Following the revolution when hopes were on the rise, Turkey supported the processes of reconstruction in Libya. However, Libyan politics took a new turn in which violence was used as an instrument when Khalifa Haftar attempted a military coup in May 2014 with the support of Egypt and the United Arab Emirates (UAE). In this period, Turkey avoided becoming a party to the conflict and defended the view that the problems should be resolved on the basis of national consensus. This approach was epitomized in the first visit of Emrullah İşler, Turkey's Special Envoy, to Libya in October 2014. During his visit, İşler met both prime ministers, one of whom 


\section{Not only did Haftar}

sabotage the negotiation

processes carried out

under the leadership of

the UN, he also obstructed

the implementation of

suggestions for a political

solution and insisted on a

military method adopt a favorable stance toward negotiations. Likewise, Turkey clearly indicated that it was not a party to the conflict in Libya by inviting Aguila Saleh, President of the HoR, to Turkey twice. However, Saleh sustained his distant attitude toward Turkey by not accepting the invitations.

Turkey advocated for clearing the way for civilian politics in Libya. Meanwhile, Khalifa Haftar tried hard to transform his power, which he had gained through military means in eastern Libya, into an authority across all of Libya. To this end, he aimed at joining the Presidential Council. Nevertheless, since he was a war criminal in the eyes of the majority of Libyans, Turkey advocated for developing an inclusive and reintegrative solution by bringing actors on whom all parties in Libya would agree to the forefront. Since Haftar's power was derived to a great extent from the support of Egypt and the UAE, Turkey expressed in various platforms the necessity to put pressure on these countries to deter them from interfering in Libya's internal affairs.

Turkey took significant steps to solve the social and economic problems the Libyan people were experiencing. Despite the security concerns, two Turkish firms went to Libya to finish the construction of two incomplete power plants in order to overcome Libya's power outages. Based on the demands of Libyans, Turkish Airlines (THY) sent its technical staff to Libya with the intention of resuming direct flights. However, this attempt was mired down by Haftar's 'air force 

proved that he would keep insisting on 'the military solution' as long as arms supplies kept flowing to him. On the other hand, the legitimate party, the GNA, was not provided the necessary support. Although the GNA called on the whole world for cooperation in the face of Haftar's aggression, international actors and the UN stayed silent. As Turkey and the GNA reckoned that as long as Haftar advanced on the ground, he and his patrons would not accede to a political solution, they wanted to tilt the military balance on the ground in favor of the GNA.

Consequently, Turkey and the GNA signed two memoranda of understanding (MoU) on November 27, 2019. The Turkish parliament approved these memoranda the following month. Based on these memoranda, the Turkish Parliament also authorized the Presidency for the deployment of troops in Libya on January 2, 2020. These memoranda augmented the defense and security cooperation between Turkey and the GNA and aimed to prepare a suitable backdrop for a political solution. The memorandum of understanding that dealt with military and security issues stipulated a comprehensive cooperation covering various sub-topics including military training experience sharing; advisory service, planning, material support, maintenance and repair, consultancy services, and the allocation of buildings and lands. It also included joint participation in military exercises and trainings and setting up a defense and security cooperation office.
The cooperation between Turkey and the GNA allowed for the building of the Berlin Conference on a realistic foundation. Had it not been for the cooperation between Turkey and GNA, the international community would have had to discuss in Berlin how to legitimize Haftar's capture of Tripoli by force of arms. Instead, as a result of the cooperation, participants of the conference negotiated how to achieve a ceasefire, how a political consensus would take form, and how to make political, economic, military, and social reforms. The participants came up with a roadmap in the Berlin Declaration; if the appropriate conditions are created and meticulously worked on for its implementation, this declaration could be a roadmap for getting through the crisis and beginning the reconstruction of Libya. However, Haftar, who on all occasions made public his rejection of a political solution, repudiated the declaration and insisted on invading Tripoli. Turkey and the GNA, on the other hand, maintained their cooperation to create the security environment that would allow for an equitable political solution.

\section{The Berlin Conference Onward}

Since Haftar maintained his defiance even during and immediately after the Berlin Conference by rejecting the outcome and carrying out his uninterrupted attacks on Tripoli, Turkey and the GNA became convinced that they had no choice but to respond militarily. In fact, what made Haftar so reckless was the unlimited support 
lent to him by certain regional and global actors. He became convinced that despite his refusal to abide by the Berlin Declaration and his continuous assaults on Tripoli, no actor or group of actors was either capable of or willing to put diplomatic pressure on him, let alone stop him physically.

To repel Haftar's assault on Tripoli, Turkey offered its military support to the GNA, in the form of military advisors, according to the MoU mentioned above. Until mid-January 2020, the military balance in north-western Libya, including wider Tripoli was in favor of Haftar's so-called Libyan Arab Armed Forces (LAAF), which was mostly composed of foreign mercenaries, militias, and radical Salafis sent by Saudi Arabia and the UAE. This superiority was especially palpable in three realms: air power, equipment, and manpower. The air superiority was maintained by airstrikes by Chinese-made Emirati drones (Wing Loong II) and warplanes.

The GNA put an end to this air superiority by more effectively using its air defense systems, which were provided by Turkey and deployed in Tripoli to curb the activity of Haftar's air forces. The GNA also made use of armed drones extensively for surveillance, and reconnaissance, as well as strike missions. The use of armed drones enabled the GNA to remove the superiority of Haftar's forces in other realms, namely equipment and manpower. The GNA's armed drones were highly functional in terms of both the detection and destruction of tanks, armored vehicles, and technical in-

\section{During the GNA's string of} military victories, many local councils and tribal figures, even from south-western Libyan provinces such as Ghat, Murzuq, and Awbari, pledged support to the GNA, relinquishing their previous alignment with the Haftar

\section{camp}

stallations, all of which often resulted in the loss of manpower as well.

The superiority of Haftar's forces in terms of manpower both quantitative and qualitative. Quantitatively, the manpower was boosted by Chadian and Sudanese Janjaweed militias in addition to eastern Libyan militias. Qualitatively, Haftar's most competent manpower component was Russian Wagner mercenaries, who allegedly engaged in sniper, mortar, and artillery missions in the outskirts of Tripoli and became the essential force that enabled Haftar's camp to encroach so close to Tripoli. The GNA responded to this twofold manpower superiority with the presence of Turkish military advisors, provided the Libyan army with better tactics, planning, command, and control. This military input by Turkey made a number of military victories possible for the GNA and forced the LAAF to relinquish a significant number of assets, areas such as Sur- 


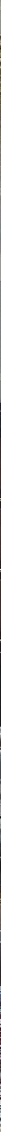

Turkish President

Recep Tayyip

Erdoğan meets

with Libyan

Prime Minister

Fayez al-Sarraj at

the Presidential

Complex on

June 6, 2020.

TCCB / MURAT

CETINMÜHÜRDAR /

AA Photo

man and Sabratha, towns between Tripoli and the Tunisian border, as well as the al-Watiya Air Base.

The military defeats of Haftar's forces at the hands of the GNA not only yielded military benefits but also led to changes in the discourse and behaviors of both domestic and external actors. During the GNA's string of military victories, many local councils and tribal figures, even from south-western Libyan provinces such as Ghat, Murzuq, and Awbari, pledged support to the GNA, relinquishing their previous alignment with the Haftar camp. Furthermore, Haftar felt the urgency to unilaterally declare himself the ruler of Libya on April 27, in order to obscure his failure and incompetence and block eastern Libyan actors from questioning his authority after the humiliating defeats. This was followed by HoR
President Aguila Saleh's 'alternative proposal for solution' with the formation of a new Presidential Council and HoR, which he also claimed that was a 'Russia-backed' proposal. ${ }^{3}$ Along with these announcements, Ahmed al-Mesmari, Haftar's spokesman, called a ceasefire for the sake of the month of Ramadan and Eid alFitr; this move was unprecedented as until then the Haftar camp had been the violator of ceasefires rather than the champion of them.

In late May, the Russian Wagner mercenaries withdrew from the southern suburbs of Tripoli with all of their heavy weapons, air defense systems, and other equipment, which caused all of Haftar's forces' fronts in and around Tripoli to fall rapidly one after another. Finally, on June 6, Abdel Fattah el-Sisi, the President of Egypt, hosted both Haftar and Aguila Saleh 
in Cairo and called for a ceasefire in Libya, which was dubbed the Cairo Declaration. The symbolism of the event was quite telling, since Haftar had been treated as the sole, all-powerful leader of Libya by many, including Egypt, but then was addressed as an equal part of a pair. The GNA's response to this call was rejection until it achieved the targets of liberating Sirte and Jufra Air Base in Libya. None of the above could have been imaginable without the decisive military defeat of Haftar's camp at the hands of the GNA with Turkey's support.

\section{Conclusion}

Historical ties between Turkey and Libya necessitate a deep sense of responsibility in Turkey's policy towards Libya; thus Turkey has come to the fore as a constructive actor. It is natural that the relations between the two nations would be built on friendship and mutual interests, given the common history of 500 years between the duo, whose collective memory has been shaped by the same cultural and civilizational space with continuing social bonds as well. Therefore, Turkey has done everything possible to resolve the crisis through political means since the revolution in 2011. Turkey has supported the implementation of the LPA, which came forward in late 2015, and the success of the institutions it created. Turkey has also called upon the international community to eliminate the barriers obstructing the implementation of the LPA.

\section{Turkey engaged in military}

and security cooperation with the GNA and sought to change the military balance on the ground in favor of the GNA

in order to render a political solution possible

Turkey had taken no step whatsoever outside the initiatives of the international community until Haftar tried to seize power at gunpoint by turning up at the gates of Tripoli. The international community almost conceded to Haftar' actions as a fait accompli by keeping silent in the face of this unlawful and illegal assault. Turkey took sides with the GNA since it foresaw that the assault would drag Libya into a deeper economic, social, and political crisis, and reckoned that this situation would serve the agendas of external actors rather than the interests of the Libyan people. Acting within the limits of legitimacy and prioritizing a political solution, Turkey acted in harmony with the GNA for taking the necessary measures to this end.

A political solution of the Libyan crisis is only possible by changing the military balance on the ground in favor of the GNA. The opposite interpretations and initiatives are not realistic. Since May 2014, Haftar has constistently rejected proposals for a political solution and hampered its implementation as long as he secured advances on the ground. Moreover, 
Haftar's international backers have been in a struggle to transform his advances on the ground into political gains and, taking advantage of his illegal advances since 2016, they have attempted to transform him into a political interlocutor. Whilst Haftar was advancing on the ground and his backers were legitimizing it, the UN's efforts to find a solution lost meaning. Under these circumstances, Turkey engaged in military and security cooperation with the GNA and sought to change the military balance on the ground in favor of the GNA in order to render a political solution possible.

Being convinced that neither Haftar nor his external patrons would heed a political solution unless they were pressured militarily, Turkey has offered military support to the GNA in the form of military advisors. This in turn multiplied the existing military capacity of the GNA, which had been helpless for a long time in the face of the coalition that sponsored Haftar's attempt to invade Tripoli. The GNA's increased military capacity then translated into a series of military victories. Haftar's defeat in many areas caused a change in the behaviors of both domestic and external actors, who for the first time questioned the capacity of Haftar and their preference to support him. The nuances among the members of the international coalition sponsoring Haftar became apparent and the existing distribution of influence among them over Haftar, or eastern Libya in general, started to change in favor of Russia at the expense of the UAE and France. In addition, the GNA became an empowered actor; after having been neglected by international actors such as prominent U.S. officials and NATO, it began to be engaged by these very actors. Bolstered by decisive military victories, both Turkey and the GNA now demand to negotiate from a position of strength and request the elimination of Haftar from the prospective solution of the Libyan crisis.

The Libyan crisis is passing through a rocky road. A civilian and democratic Libya could be built by means of a multidimensional strategy both on the negotiation table and on the ground. Turkey would support Libyans' efforts to build a civilian and democratic Libya as soon as the military balance on the ground renders a backdrop for a political solution. Turkey will continue to take sides with the Libyan people and the GNA in all processes to support the comprehensive security sector, public administration, and the economic, political, and social reforms verbalized in the Berlin Declaration.

\section{Endnotes}

1. "Batı ve Kaddafi Makasındaki Libya," SETA, (May, 2011), retrieved from http://file.setav.org/Files/ Pdf/20121126135254_seta-bati_ve_kaddafi_makasinda_libya.pdf.

2. "Türkiye, Libya'da El Hasi ile Görüşen İlk Ülke Oldu," BBC Türkçe, (October 22, 2014), retrieved from https://www.bbc.com/turkce/haberler/201 4/10/141022_turkiye_libya_emrullah_isler.

3. Hamdi Yıldız and Leila Thabti, "Russia Asked Haftar to Declare Truce: Saleh", Anadolu Agency, (May 2, 2020), retrieved from https://www.aa. com.tr/en/middle-east/russia-asked-haftar-todeclare-truce-saleh/1826200. 